\title{
Consumption of marine snow by two species of juvenile mullet and its contribution to their growth
}

\author{
Earl T. Larson*, Alan L. Shanks** \\ Grice Marine Biological Laboratory, University of Charleston, 205 Fort Johnson, Charleston, South Carolina 29412, USA
}

\begin{abstract}
Juvenile white mullet Mugil curema and juvenile striped mullet Mugil cephalus actively ingested marine snow in the laboratory. This is the first experimental verification of the consumption of marine snow by a vertebrate. The stomach contents of fish fed marine snow in the laboratory were compared to fish collected from the Charleston Harbor estuary, South Carolina, USA, and the coastal Atlantic Ocean. Results suggest that juvenile mullet consume marine snow in the natural environment. In food choice experiments in which mullet were offered a choice between marine snow and zooplankton (Artemia sp.), consumption of marine snow was inversely related to zooplankton concentrations. Mullet assimilated organic matter and total amino acids from marine snow with efficiencies of 49.2 and $55.8 \%$, respectively. These efficiencies are comparable to those of fish feeding on benthic detritus. The contribution of marine snow to the growth of juvenile mullet was tested in growth experiments by feeding mullet different combinations of marine snow and zooplankton (Artemia sp.). Mullet did not exhibit positive growth on a diet of marine snow (specific growth rate $=-1.34 \% \mathrm{~d}^{-1}$ ). Marine snow contributed to the diet of mullet by slowing weight loss (by $50 \%$ ), especially when complemented with zooplankton (an additional 50\%).
\end{abstract}

KEY WORDS: Marine snow Feeding Growth Mullet - Detritus Aggregates $\cdot$ Foodweb Planktivores

\section{INTRODUCTION}

Marine snow, naturally occurring macroscopic aggregates of suspended particles, is a nearly universal component of the suspended matter in the ocean (Trent et al. 1978, Alldredge \& Silver 1988). In an estuary and near-shore waters, marine snow consists of detritus, mineral grains, phytoplankton, and microorganisms bound loosely in a mucous matrix (Eisma 1986, Shanks \& Edmondson 1990). Macroaggregates of marine snow range in size from half a millimeter up to several centimeters in diameter (Alldredge \& Silver 1988). Marine snow is nearly always present in coastal and estuarine environments, with concentrations reaching hundreds of aggregates per liter (Shanks \& Edmondson 1990).

\footnotetext{
- Present address: Department of Environmental, Population and Organismic Biology, University of Colorado, Boulder, Colorado 80309-0334, USA

-Addressee for correspondence. Present address: Oregon Institute of Marine Biology, University of Oregon, PO Box 5389, Charleston, Oregon 97420,USA.E-mail: ashanks@ oimb.uoregon.edu
}

Although researchers have speculated that marine fauna may consume marine snow (Silver et al. 1978. Alldredge \& Silver 1988, Banse 1990), there has been little direct investigation of the consumption of marine snow and no study has been undertaken to investigate consumption of marine snow by fishes. Because approximately $83 \%$ of the nematodes in the water column were on marine snow, Shanks \& Edmondson (1990) suggested that nematodes could be used as a biological tracer of marine snow in an organism's diet. Lewis \& Peters (1984) found that the frequency of holoplanktonic zooplankton and nematodes in the diet of juvenile menhaden was the same, yet zooplankton were far more abundant than nematodes in the water column (Shanks \& Edmondson 1990). This observation, coupled with the concentrations of nematodes on marine snow, suggested that juvenile menhaden may have been feeding on marine snow.

Flocculation of microparticles into macroaggregates could increase potential consumption of this material by a wider range of organisms. Previous studies on filter-feeding fishes have shown that as food particle size increases feeding efficiency also increases (Wright 
et al. 1983, Friedland et al. 1984). McIntyre (1983) found that gizzard shad Dorosoma cepedianum collected 24 times more food from tanks in which algal flocculation was induced by adding clay particles to the water, as compared to tanks without flocculation. Aggregation of particles, therefore, can increase the feeding efficiency of filter-feeding fish.

The purpose of this study was to examine consumption of marine snow by juveniles of 2 teleost species, the white mullet Mugil curema and the striped mullet Mugil cephalus. Mullet are very flexible in their feeding habits with possible ontogenetic shifts in diet occurring with the transition from post-larva to adult. The occurrence of detritivory in adult mullet is well documented (Thomson 1954, Odum 1968a, Moriarity 1976). Little consensus exists on the food of juvenile mullet, however. They have been reported to feed on detritus (Thomson 1954, Ching 1977), algae (Odum 1968b, De Silva \& Wijeyaratne 1977), and zooplankton (Lasiak \& McLachlan 1987, Pisarevskaya \& Aksenova 1991). Several authors report that young mullet are planktivorous and switch to detritivory as they increase in size (De Silva \& Wijeyaratne 1977, Romer \& McLachlan 1986, Pisarevskaya \& Aksenova 1991). Due to the flexible nature of their diet, and the fact that juveniles would encounter marine snow in the wild, mullet were selected to investigate the potential of marine snow as food for marine and estuarine fishes. Previous experiments with omnivorous fishes other than mullet have shown that invertebrates were preferred over detritus (Ahlgren 1990a). These factors prompted us to include zooplankton as a factor in the study. The primary objectives of this study were: (1) to determine if juvenile mullet consume marine snow; (2) to determine if juvenile mullet prefer marine snow over zooplankton; (3) to determine the ability of marine snow to promote growth in juvenile mullet; and (4) to determine the ability of juvenile mullet to assimilate nutrients from marine snow.

\section{MATERIALS AND METHODS}

Fish collection and holding. Juvenile white mullet Mugil curema (25 to $40 \mathrm{~mm}$ standard length. SL) were collected between May and July 1992 by seining a tidal creek on Bull Island, South Carolina, USA. Fish were transported to the Grice Marine Biological Laboratory (GMBL) and held in a recirculating seawater system where they were maintained on a mixed diet of Artemia larvae and commercial herbivore flake food that had been ground in a mortar and pestle. Fish were held for 3 to $14 \mathrm{~d}$ before being used in experiments.

Juvenile striped mullet Mugil cephalus (20 to $40 \mathrm{~mm}$ SL) were obtained in October 1992 from the Oceanic
Institute, Honolulu, Hawaii, USA. They were produced by induced spawning of adult mullet caught in Kaneohe Bay, HI. They were kept in a manner similar to that described for the white mullet.

Laboratory formation of marine snow. Laboratorymade artificial marine snow was generated following the methods of Shanks \& Edmondson (1989). Cylindrical tanks ( $20 \mathrm{~cm}$ diameter $\times 10 \mathrm{~cm}$ deep, $3 \mathrm{l} \mathrm{vol}$ ) of unfiltered seawater from Charleston Harbor estuary, South Carolina, USA, were rotated on a roller table until particles in the seawater formed aggregates. A previous study demonstrated that these artificial aggregates have the same composition as natural marine snow (Shanks \& Edmondson 1989).

To verify consumption of marine snow by mullet, a tracer $[1 \mu \mathrm{m}$ diameter fluorescent latex microspheres (Polysciences, Inc., Warrington, PA)] was incorporated into laboratory-made marine snow. The beads were coated with protein (powdered milk solution, $3 \% \mathrm{w} / \mathrm{v}$ ), which maximized incorporation. The beads were diluted $1: 1 \times 10^{6}$ with unfiltered seawater Preliminary experiments were conducted to test the feasibility of these microspheres as tracer for the marine snow. At this dilution, $96 \%$ of the beads were incorporated into marine snow $(\mathrm{n}=4$, S.E $=1.2 \%$ ).

Food choice experiments. Artemia sp. larvae were used as the experimental zooplankter. It was hypothesized that the consumption of Artemia would be directly related to Artemia concentration and that consumption of marine snow would be inversely related to Artemia concentration. Artemia were cultured from eggs for $96 \mathrm{~h}$ at $21^{\circ} \mathrm{C}$. Unhatched eggs were separated from the Artemia by rinsing with seawater through a $300 \mu \mathrm{m}$ sieve. Marine snow was made as described previously, and Artemia added to the tanks before marine snow formation. Initial experiments were conducted to determine if Artemia associated with marine snow. Only $0.8 \%$ of the Artemia associated with the marine snow ( $\mathrm{n}=4$, $\mathrm{SE}=0.3 \%$ ).

Tanks were filled with unfiltered seawater, an aliquot of fluorescent microspheres, and one of the following concentrations of Artemia: $120,60,30$, and $0 \mathrm{~J}^{-1}$. To allow for proper marine snow formation, the tanks were rolled for $6 \mathrm{~h}, 1$ fish was placed in each tank and the tanks returned to the roller table. Tanks contained more marine snow than could be consumed in the experimental feeding period. The mullet were observed while they fed in the roller tanks, and their behaviors qualitatively described using previously published classifications of feeding behaviors (Leong \& O'Connell 1969, Johnson \& Vinyard 1987). Fish were allowed to feed for $1 \mathrm{~h}$ and, at the end of this feeding period, they were anesthetized with MS222. The abdomens were slit from operculum to anus and the fish were fixed in $10 \%$ formalin. 
Gut content analyses were performed by dissecting stomachs from the fish and sorting the contents. Artemia were separated from the marine snow and counted. Marine snow was placed in a microcentrifuge tube, suspended in $1 \mathrm{ml}$ distilled water and sonicated in a bath sonicator for 20 min to break up any intact aggregates. The sample was vortexed. A $20 \mu \mathrm{l}$ aliquot was removed from the center of the tube, placed on a glass slide and examined under a microscope using epifluorescence. The number of fluorescent microspheres in the sample was counted and used to determine the amount of marine snow consumed using the conversion factors detailed below.

Conversion factors. In order to convert the results of stomach content analysis into units that could be compared to each other, ash-free dry mass (AFDM) conversion factors were determined. Ten replicate samples of 100 Artemia, and 5 replicate samples of 100 aggregates were collected from rolling tanks using a syringe (Shanks \& Edmondson 1989) and dried overnight at $105^{\circ} \mathrm{C}$ in pre-ashed aluminum pans. Replicates were taken on different days to account for day-to-day variation in marine snow (Shanks \& Edmondson 1989). Samples were cooled in a dessicator, weighed to the nearest $0.01 \mathrm{mg}$, ashed in a muffle furnace for 1 h at $550^{\circ} \mathrm{C}$, cooled and reweighed. To estimate the average number of beads in each aggregate, 15 additional aggregates were removed from the same tanks as the 100 aggregates used to calculate dry mass and AFDM, and the beads counted as described previously. The number and size of aggregates were determined by projecting enlarged photographs of marine snow in the roller tanks onto a digitizing pad (Shanks \& Edmondson 1989). The AFDM as a percentage of the dry mass was $93 \%$ $(\mathrm{n}=10, \mathrm{SE}=1.47 \%)$ for Artemia and $30 \%(\mathrm{n}=5, \mathrm{SE}=$ $2.03 \%$ ) for marine snow. This provided conversion factors of $4.53 \mathrm{\mu g}$ AFDM per Artemia and $8.74 \mu \mathrm{g}$ AFDM per aggregate. The average concentration of aggregates per tank was $292(n=12, \mathrm{SE}=40.3$ ). The average diameter of marine snow was $3.38 \mathrm{~mm}$ ( $\mathrm{n}=$ 12, $\mathrm{SE}=0.25)$. The average length of Artemia was $0.9 \mathrm{~mm}(\mathrm{n}=5, \mathrm{SE}=0.16)$.

Growth experiments. Feeding experiments were conducted to determine the ability of marine snow and other foods to produce growth in mullet. Five different treatments were used: (1) unlimited zooplankton (3000 to 5000 Artemia $1^{-1}$ ); (2) unlimited marine snow + limited zooplankton (60 Artemia $\mathrm{l}^{-1}$ ); (3) limited zooplankton (60 Artemia ${ }^{-1}$ ); (4) unlimited marine snow; and (5) unfed. An unlimited treatment was defined as containing more Artemia or marine snow than a fish could consume in a $24 \mathrm{~h}$ period. The concentration of Artemia used in the limited zooplankton treatment was similar to average copepod concentra- tions in southeastern estuarine waters (Fulton 1984). Two treatments ( 2 and 4 ) had marine snow made from unfiltered seawater. To prevent marine snow from forming in treatments without marine snow $(1,3$ and 5), seawater was filtered through $25 \mu \mathrm{m}$ and $1 \mu \mathrm{m}$ filter bags before filling roller tanks. This removed particles and no marine snow formed when the tanks were rolled. It was hypothesized that fish would exhibit the best growth on a diet of unlimited Artemia. This diet does not reflect the natural environment, however. We hypothesized that the next best growth would be observed on a more natural mixed diet of unlimited marine snow and limited Artemia.

Fish were maintained on a $14 \mathrm{~h}$ light : $10 \mathrm{~h}$ dark photoperiod, and water temperature was maintained at $21^{\circ} \mathrm{C} \pm 2^{\circ} \mathrm{C}$ for white mullet and $24^{\circ} \mathrm{C} \pm 2^{\circ} \mathrm{C}$ for striped mullet. Once a day, water was carefully siphoned off and replaced with fresh filtered or unfiltered seawater depending on treatment. At this time new Artemia were also added. Salinities remained between 28 and 32 PSU (practical salinity units). The oxygen concentrations in these tanks did not drop below the normal range of estuarine waters.

Fish were weighed on Days 1 and 14. Individuals were held in a net for $10 \mathrm{~s}$ to remove excess water and then placed in a beaker containing $100 \mathrm{ml}$ of seawater tared to zero on a top loading balance. Weight was read to the nearest $0.01 \mathrm{~g}$. Preliminary experiments were performed to insure the high repeatability of this method ( $\mathrm{n}=10, \mathrm{SE}=0.02 \mathrm{~g}$ ). After $14 \mathrm{~d}$ the experiment was stopped. The specific growth rate (SGR) was calculated using the following equation (Ricker 1979):

$$
\operatorname{SGR}\left(\% \mathrm{~d}^{-1}\right)=100 \times\left(\ln W_{2}-\ln W_{1}\right) / t
$$

where $W_{1}$ is the initial weight, $W_{2}$ is the final weight, and $t$ is the number of days in the experiment.

Laboratory assimilation experiments. Assimilation efficiencies of striped mullet fed laboratory-made marine snow were determined. Five replicate groups of 40 fish were placed 2 fish per tank and rolled on the roller table. Fish in these tanks were acclimated to feeding on marine snow for $24 \mathrm{~h}$. Fish were removed for $6 \mathrm{~h}$ while water was replaced with fresh unfiltered seawater and new marine snow formed. After the formation of new marine snow, the fish were returned to the tanks and were allowed to feed for 3 to $4 \mathrm{~h}$ and then anesthetized. The digestive tract was excised and the foregut and hindgut separated. The foregut was defined as the anterior $1 / 4$ of the gut, comprising the stomach and the esophagus. The hindgut was defined as the posterior $1 / 4$ of the gut. In order to have enough material for the chemical analyses, the contents of the foreguts and hindguts of 
each group of 40 fish were pooled in pre-ashed and weighed foil pans. The samples were dried overnight at $110^{\circ} \mathrm{C}$.

Organic content of the foregut samples and hindgut samples was determined by burning off the organic matter at $550^{\circ} \mathrm{C}$ for $1 \mathrm{~h}$ to obtain AFDM. Hydrolysisresistant organic matter (HROM), primarily cellulose and chitin, was measured using the method of Buddington (1980).

Assimilation efficiency $(\% \mathrm{AE}=$ the amount of nutrient removed from the digestive tract expressed as a percentage of the amount ingested) was calculated by Conover's (1966) indigenous dietary marker technique. HROM was used as the indigenous undigested dietary marker. Assimilation was calculated by comparing the organic (nutrient) and HROM (indigestible marker) content of the foregut to the organic and HROM content of the hindgut using the following equation (modified from Conover 1966):

$$
\% A E=\left[\left(N_{\mathrm{f}} / M_{\mathrm{f}}-N_{\mathrm{h}} / M_{\mathrm{h}}\right) /\left(N_{\mathrm{f}} / M_{\mathrm{f}}\right)\right] \times 100
$$

where $N_{\mathrm{f}}$ and $N_{\mathrm{h}}$ are the concentrations of nutrient in the foregut and hindgut, respectively, and $M_{\mathrm{f}}$ and $M_{h}$ are the concentrations of indigestible marker in the foregut and hindgut, respectively.

Assimilation of amino acids was also determined. Total amino acid concentration in the foregut and hindgut was determined via peptide detection (Allen 1981). Ninhydrin was used to give a color change, and absorbances were read in a spectrophotometer at $570 \mathrm{~nm}$ using a $1 \mathrm{~cm}$ path length cell. To estimate total amino acid content, a standard curve was obtained using bovine serum albumin against which the samples were compared. Assimilation efficiency for total amino acids was calculated using the equation above, with amino acids as the nutrient and HROM as the indigestible marker.

Field comparisons. To determine whether mullet are consuming marine snow in their natural environment, the stomach contents of fish fed marine snow in the lab were compared to the stomach contents of field caught fish. Field specimens were obtained from the reference collections of the South Carolina Wildlife and Marine Resource Division (Wenner et al. 1979, Wenner et al. 1982). Three sets of 10 fish each were examined: (1) Mugil curema from offshore waters; (2) M. cephalus from offshore waters; and (3) M. cephalus from the Charleston Harbor estuary. All specimens were preserved in $10 \%$ formalin. Offshore samples were collected using a neuston net and estuarine samples were collected using a Cobb trawl. Stomach contents were removed, spread on a Sedgewick Rafter slide, and examined qualitatively using a compound microscope. Stomachs of mullet fed marine snow in the laboratory were used for comparison.

\section{RESULTS}

\section{Food choice experiments}

The amount of marine snow consumed by both species of mullet was inversely related to the concentration of Artemia in the treatment (Figs. 1 \& 2), while the amount of Artemia consumed by both species was directly related to Artemia concentrations (Figs. 3 \& 4). Even at the highest Artemia concentration, however, the juvenile mullet continued to consume marine snow

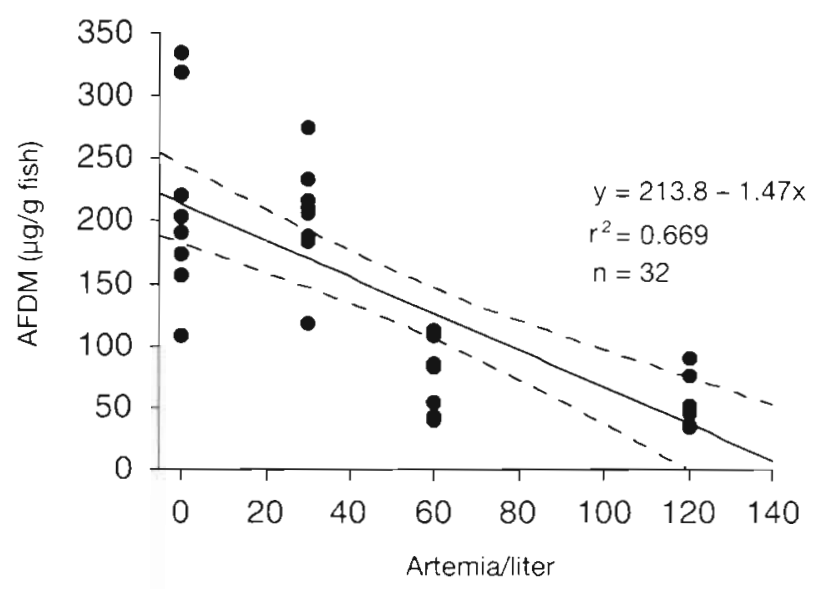

Fig. 1. Mugil curema. Marine snow consumption ( $\mu$ g AFDM $g^{-1}$ fish) by juvenile white mullet plotted against Artemia concentrations. There were 8 replicate fish in each treatment. Each data point represents the consumption by 1 fish. Dashed lines represent $95 \%$ confidence intervals around the regression line

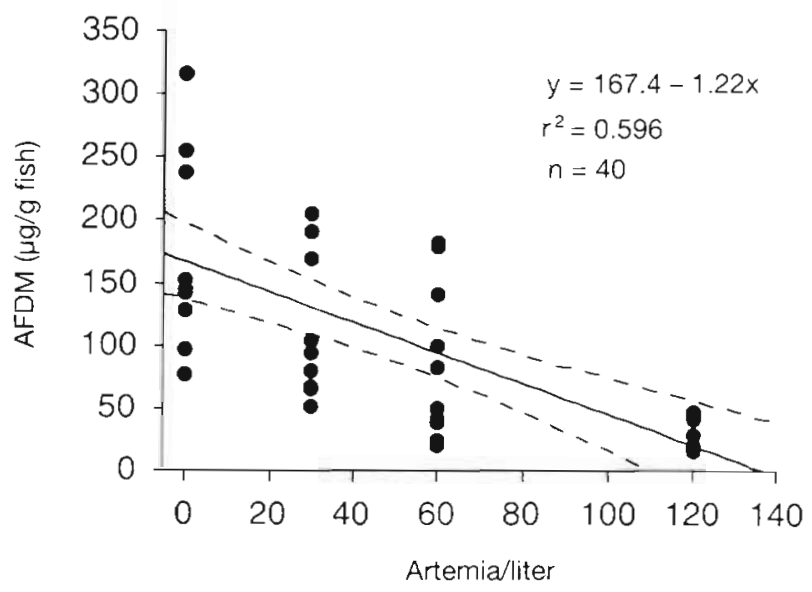

Fig. 2. Mugil cephalus. Marine snow consumption ( 1 g AFDM $\mathrm{g}^{-1} \mathrm{fish}$ ) by juvenile striped mullet plotted against Artemia concentrations. There were 10 replicate fish in each treatment. Each data point represents the consumption by $1 \mathrm{fish}$. Dashed lines represent $95 \%$ confidence intervals around the regression line 


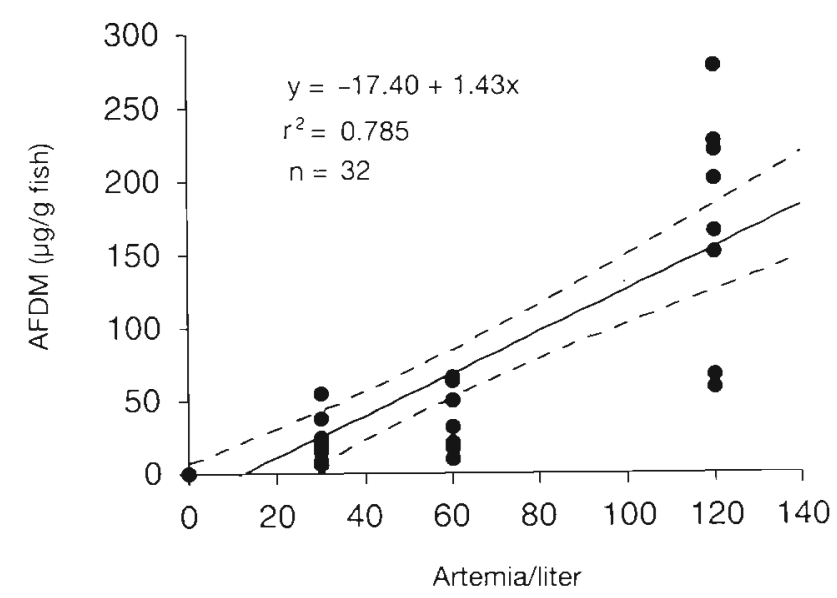

Fig. 3. Mugil curema. Artemia consumption ( $\mu$ g AFDM g-1 fish) by juvenile white mullet plotted against Artemia concentrations. There were 8 replicate fish in each treatment. Each data point represents the consumption by 1 fish. Dashed lines represent $95 \%$ confidence intervals around the regression line-

(6.1 and $3.4 \mathrm{~h}^{-1}$ for juvenile white and striped mullet, respectively; Table 1). In the tanks without Artemia both species of mullet consumed more than 20 aggregates $\mathrm{h}^{-1}$ (Table 1 ).

Mullet were observed to ingest both marine snow and Artemia. Mullet fed using 2 different methods, biting and pump-filtering. Juvenile mullet appeared to use pump-filtering when feeding on marine snow. A burst of tail strokes (approximately 4 to 6 ) was followed by a short glide. During the entire motion, the fish pumped water with its jaws and buccal cavity. This action usually occurred as the fish swam into a patch of marine snow, and aggregates were seen being sucked into the mouth. When feeding on Artemia, mullet were biting. During biting, the fish

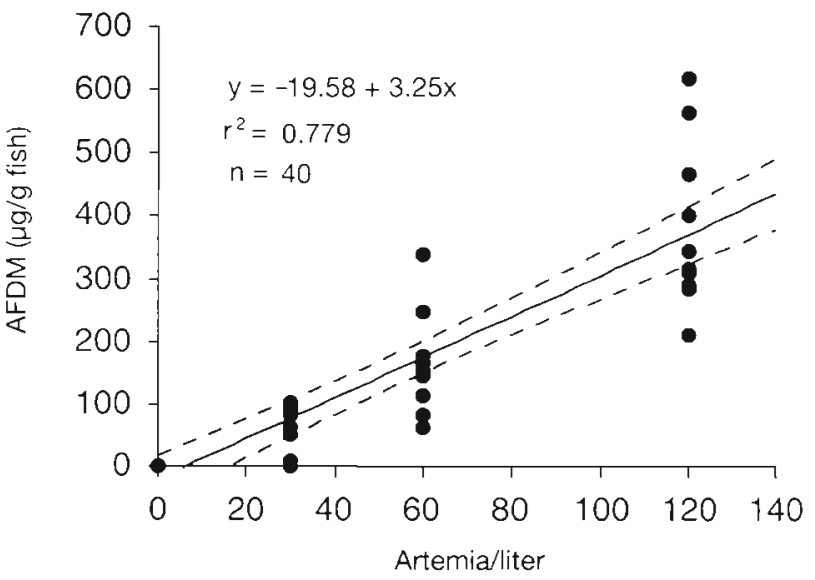

Fig. 4. Mugil cephalus. Artemia consumption ( $\mu$ g AFDM g ${ }^{-1}$ fish) by juvenile striped mullet plotted against Arternia concentrations. There were 10 replicate fish in each treatment. Each data point represents the consumption by $1 \mathrm{fish}$. Dashed lines represent $95 \%$ confidence intervals around the regression line

employed a shorter swimming burst (usually 2 or 3 tail beats) followed by a very short glide in which the mullet quickly opened and closed its mouth once in a bite around a prey item. If there were many zooplankters present, this was quickly followed by another feeding burst. With lower zooplankton concentrations, the mullet paused to locate a second prey before it performed another feeding burst. The filtering method was much more rhythmic and regular than biting which seemed erratic. During biting, fish turned much more frequently to attack prey. During filtering, fish swam more slowly and turned less frequently. Fish generally fed in mid-water but were occasionally observed feeding on the bottom or sides of the tank.

Table 1. Mugil curema and $M$. cephalus. Consumption of marine snow and Artemia per gram weight of fish by juvenile white mullet (mean weight of fish $=0.91 \mathrm{~g}, \mathrm{n}=32$ ) and juvenile striped mullet (mean weight of fish $=0.40 \mathrm{~g}, \mathrm{n}=40$ ) in $1 \mathrm{~h}$ feeding trials. Data are means (SEM), $n=8$ for $M$. curema and $n=10$ for $M$. cephalus. AFDM: ash free dry mass

\begin{tabular}{|c|c|c|c|c|c|c|}
\hline & \multicolumn{3}{|c|}{ Artemia } & \multicolumn{2}{|c|}{ Marine snow } & \multirow{2}{*}{$\begin{array}{l}\text { Total } \\
\mu g \text { AFDM } \\
\text { consumed }\end{array}$} \\
\hline & $\begin{array}{l}\text { Number } \\
\text { available }\end{array}$ & $\begin{array}{l}\text { Number } \\
\text { consumed }\end{array}$ & $\begin{array}{l}\mu \mathrm{g} \text { AFDM } \\
\text { consumed }\end{array}$ & $\begin{array}{l}\text { Number } \\
\text { consumed }\end{array}$ & $\begin{array}{l}\mu \mathrm{g} \text { AFDM } \\
\text { consumed }\end{array}$ & \\
\hline Mugil curema & $\begin{array}{r}120.0 \\
60.0 \\
30.0 \\
0.0\end{array}$ & $\begin{array}{r}37.8(5.73) \\
8.0(2.41) \\
5.5(1.17) \\
0.0(0.00)\end{array}$ & $\begin{array}{c}171.1(32.11) \\
36.4(7.52) \\
23.8(5.60) \\
0.0(0.00)\end{array}$ & $\begin{array}{r}6.1(0.78) \\
8.7(1.13) \\
23.3(1.81) \\
24.4(2.65)\end{array}$ & $\begin{array}{c}53.7(6.80) \\
76.0(9.84) \\
203.6(15.84) \\
213.2(23.13)\end{array}$ & $\begin{array}{l}224.8(29.85) \\
112.5(10.69) \\
227.4(19.26) \\
213.2(23.13)\end{array}$ \\
\hline Mugil cephalus & $\begin{array}{r}120.0 \\
60.0 \\
30.0 \\
0.0\end{array}$ & $\begin{array}{r}83.9(7.41) \\
36.5(5.25) \\
12.9(2.71) \\
0.0(0.00)\end{array}$ & $\begin{array}{r}380.2(37.06) \\
161.5(23.76) \\
58.4(12.38) \\
0.0(0.00)\end{array}$ & $\begin{array}{r}3.4(0.46) \\
9.9(2.30) \\
12.7(2.06) \\
21.3(4.04)\end{array}$ & $\begin{array}{c}29.9(4.03) \\
86.2(20.09) \\
110.7(18.02) \\
186.5(28.71)\end{array}$ & $\begin{array}{l}410.1(37.29) \\
251.7(33.99) \\
169.3(18.53) \\
186.5(28.71)\end{array}$ \\
\hline
\end{tabular}


Table 2. Mugil curema and $M$. cephalus. Initial weight $\left(W_{1}\right)$, final weight $\left(W_{2}\right)$ and specific growth rate (SGR) for juvenile white mullet [final mean standard length $=29.4 \mathrm{~mm}(S E=0.70, \mathrm{n}=30)$ ] and juvenile striped mullet [final mean standard length $=$ $24.7 \mathrm{~mm}$ (SE $=0.30, \mathrm{n}=25)$ ] feeding on 5 different diets for $14 \mathrm{~d}$. Data are means (SEM), $n=6$ for $M$. curema and $\mathrm{n}=5$ for $M$. cephalus. SGR for juvenile striped mullet designated by different letters are significantly different (Student-Newman-Keuls, $\mathrm{p}<$ 0.05). SGR for white mullet were analyzed using the Kruskal-Wallis test and could not be subsequently analyzed with a multiple comparisons test

\begin{tabular}{|c|c|c|c|c|c|}
\hline Diet & $W_{1}(\mathrm{~g})$ & $W_{2}(g)$ & $\operatorname{SGR}\left(\% d^{-1}\right)$ & Mortality & Mean life (d) \\
\hline \multicolumn{6}{|l|}{ Mugil curema } \\
\hline Unlimited Artemia & $0.53(0.03)$ & $0.64(0.03)$ & $1.65(0.16)$ & 2 & $13(0.88)$ \\
\hline $\begin{array}{l}\text { Unlimited marine snow } \\
\quad+\text { limited Artemia }\end{array}$ & $0.48(0.06)$ & $0.45(0.06)$ & $-0.89(0.35)$ & 3 & $11(1.23)$ \\
\hline Limited Artemia & $0.58(0.17)$ & $0.50(0.15)$ & $-1.62(0.74)$ & 6 & $8(0.52)$ \\
\hline Unlimited marine snow & $0.54(0.13)$ & $0.45(0.10)$ & $-1.82(0.44)$ & 6 & $9(1.05)$ \\
\hline Unfed & $0.53(0.15)$ & $0.41(0.12)$ & $-3.57(0.45)$ & 6 & $8(0.34)$ \\
\hline \multicolumn{6}{|l|}{ Mugil cephalus } \\
\hline Unlimited Artemia & $0.19(0.05)$ & $0.27(0.01)$ & $2.59(0.57) \mathrm{a}$ & 0 & $14(0.00)$ \\
\hline $\begin{array}{l}\text { Unlimited marine snow } \\
+ \text { limited Artemia }\end{array}$ & $0.32(0.01)$ & $0.29(0.02)$ & $-0.89(0.40) b$ & 2 & $13(0.40)$ \\
\hline Limited Artemia & $0.22(0.02)$ & $0.17(0.01)$ & $-1.89(0.85) \mathrm{b}$ & 3 & $13(0.24)$ \\
\hline Unlimited marine snow & $0.23(0.03)$ & $0.19(0.04)$ & $-1.34(0.40) b$ & 4 & $13(0.51)$ \\
\hline Unfed & $0.30(0.02)$ & $0.19(0.01)$ & $-3.68(0.26) c$ & 2 & $13(0.73)$ \\
\hline
\end{tabular}

\section{Growth experiments}

The 5 different experimental diets produced significantly different growth in juvenile white mullet (Kruskal-Wallis test, $\mathrm{p}<0.0005$ ). The combination of limited Artemia and unlimited marine snow resulted in weight loss at approximately half the rate of fish that received only Artemia or only marine snow. Fish in both the latter treatments lost weight at half the rate of unfed fish (Table 2).

As expected, the fish fed on unlimited Artemia gained weight, and the unfed fish exhibited severe weight loss (Table 2). The difference in growth between the 5 groups of striped mullet was highly significant (ANOVA, $p<0.0001$ ). With the StudentNewman-Keuls test, unfed fish and those receiving unlimited invertebrates were significantly different from the other 3 groups: marine snow alone; limited Artemia + marine snow; and Artemia alone. These 3 treatments did not produce positive growth. The combination of limited Artemia and unlimited marine snow produced weight loss at approximately half the rate in fish recelving only Artemia or only marine snow; fish in both these treatments lost weight at half the rate of unfed fish.

\section{Laboratory assimilation experiments}

Juvenile striped mullet assimilated $49.2 \%$ (SE = $14.2 \%, \mathrm{n}=5$ ) of the organic matter contained in marine snow. Total amino acids were assimilated by juvenile striped mullet with an efficiency of $55.8 \%$ (SE $=11.6 \%$, $\mathrm{n}=5$ ). Using marine snow from pooled foregut contents, marine snow made in the laboratory and consumed by these fish appeared to contain approximately $33.7 \%(\mathrm{SE}=9.9 \%, \mathrm{n}=5$ ) organic material, $4.2 \%(\mathrm{SE}=0.6 \%, \mathrm{n}=5)$ amino acids, and $2.5 \%$ ( $\mathrm{SE}=$ $0.6 \%, \mathrm{n}=5) \mathrm{HROM}$.

\section{Field comparisons}

The stomach contents of a mullet fed marine snow in the laboratory appear at first to contain a homogeneous mass of amorphous matter. Under closer inspection, the components can be identified as: detrital fragments, mineral grains, diatoms and other phytoplankton, crustacean exoskeleton fragments, and sometimes whole invertebrates. The same components can be identified in the stomach contents of mullet collected from the field.

Of the white mullet (mean SL $=20.5 \mathrm{~mm}, \mathrm{n}=10$ ) collected from offshore samples, 5 guts contained exoskeleton fragments, 4 contained exoskeleton fragments and amorphous material that may be marine snow, and 1 gut was empty. One of the guts containing exoskeleton fragments contained an intact copepod and a larval polychaete. Juvenile striped mullet (mean $\mathrm{SL}=18.1 \mathrm{~mm}, \mathrm{n}=10$ ) collected of shore yielded similar results. Eight stomachs contained exoskeleton fragments and amorphous material that appeared to be of detrital origin, and 2 of the stomachs contained amorphous detrital material alone. 
The stomachs of juvenile striped mullet collected from the Charleston Harbor estuary (mean SL = $23.1 \mathrm{~mm}, \mathrm{n}=10$ ) contained detrital material and some zooplankton. The 10 stomachs contained 59 harpacticoid copepods, 2 larval polychaetes and 1 nematode. Numerous exoskeleton fragments were also seen, and the volume of detritus was roughly equal to the volume of invertebrates

\section{DISCUSSION}

This work is the first to demonstrate experimentally the consumption of marine snow by fishes. Juvenile mullet consumed between 3 and 24 aggregates $\mathrm{h}^{-1}$ (Table 1). In coastal waters, assuming a high aggregate abundance of $20 \mathrm{l}^{-1}$ (Trent et al. 1978), juvenile mullet could consume all of the marine snow in a liter in from 1 to $6 \mathrm{~h}$. Within an estuary, where aggregate concentrations are often around $100 \mathrm{l}^{-1}$, juvenile mullet could consume all of the marine snow in a liter in about 5 to $30 \mathrm{~h}$.

There is little published evidence for the consumption of marine snow by any metazoan. Alldredge (1976) presented field observations of the sergeant major Abudefduf saxatilis which suggested that they might have been feeding on larvacean houses, one source of marine snow. Gerber \& Marshall (1974) provided evidence from stomach contents of copepods for the consumption of reef derived aggregates. Suh et al. (1991) suggest from the examination of gut contents that euphausid larvae were consuming aggregates. Bochdansky \& Herndl (1992) experimentally tested the consumption of marine snow by planktonic crustaceans. They used methods similar to those used in this study to demonstrate the consumption of marine snow by copepods. Their methods differ from those used in this study in 3 ways: (1) copepods were offered normal laboratory-made marine snow as well as aggregated phytoplankton; (2) consumption was not quantified through the use of a marker, but rather by measuring plant pigment concentrations from the gut contents; and (3) tanks were allowed to roll for $3 \mathrm{~d}$ before copepods were introduced into the roller tanks. Two problems exist with these methods: (1) plant pigments are not a reliable way to quantify marine snow consumption because plant pigments contribute little to the total amount of material in marine snow and are also found in the surrounding water (Shanks \& Edmondson 1989); and (2) because it is not yet known how the palatability of the marine snow changes with age, animals should be introduced into the roller tanks as soon after marine snow formation as possible. A period of $3 \mathrm{~d}$ is potentially too long to wait and may decrease the palatability of marine snow.
The fact that some species of fishes can consume marine snow may lead to several changes in the way we view oceanic trophic relationships. Fishes consuming marine snow are feeding on primary producers, consumers, degraders, and detritus; they are not feeding exclusively on primary consumers. By feeding at a lower trophic level, mullet may be more efficient at transferring energy and materials up the food web. Due to their feeding on aggregates, juvenile mullet can feed on extremely small particles (e.g. bacteria attached to particles). There is a minimum-sized particle that can be retained on the gill rakers of a species (Wright et al. 1983). Therefore, there are size classes of plankton that should be too small for certain fish species to consume. Marine snow combines particles (especially smaller ones) of various sizes into larger aggregates. The juvenile mullet were feeding on particles that were both far smaller than size-based food web models would predict and smaller than one would predict based on the minimum-sized particle that can be retained on a mullet gill raker (Odum 1968a, Marais 1980). Due to the aggregations of particles into marine snow, juvenile mullet were able to consume particles orders of magnitude smaller than predicted and exploit a food source previously thought to be unavailable.

Both species of mullet ingested marine snow in laboratory experiments, and the consumption of marine snow was inversely related to Artemia concentrations. Although consumption of marine snow by fishes has not been previously reported, laboratory studies similar to this one have investigated consumption of detritus by freshwater fishes. Ahlgren (1990a) found that consumption of freshwater detritus by white suckers was inversely related to Artemia concentration. Field studies on the diets of fishes in their natural habitat where invertebrate concentrations vary seasonally have shown that when invertebrates were available in quantity they were the primary dietary component. In times of lower invertebrate abundance, however, detritus comprised a large part of the diet (LoweMcConnell 1964, Prejs \& Prejs 1987, Ahlgren 1990a).

Striped mullet consumed much more total material when concentrations of Artemia were high (Table 1). Therefore, striped mullet appeared to feed much more vigorously on Artemia than on marine snow. There could be several explanations for this behavior. Certain amino acids are known to stimulate feeding behavior in fishes (Carr 1976, Goh \& Tamura 1980). Detritus usually contains low levels of amino acids (Bowen 1987) and, like other detritus, marine snow was also low in amino acid content. Artemia may elicit a stronger feeding response due to their higher amino acid content.

Visual cues might be important in the initiation of feeding. Juvenile striped mullet appear to bite Artemia 
and filter marine snow. In previous studies that have compared the relationship between filter and particulate feeding (Johnson \& Vinyard 1987, Ehlinger 1989), particulate feeding is a result of active visual selection, whereas filter feeding is not. If mullet are foraging primarily on the basis of visual cues, zooplankton that move by fast jerky movements will produce more visual cues than marine snow and could stimulate increased feeding.

Although consumption of marine snow did not produce positive growth in juvenile mullet, it contributed to the diet of the mullet by slowing weight loss, especially when complemented with Artemia. Other studies have shown that detritus alone will not produce positive growth in omnivorous fishes (Prinslow et al. 1974, Mundahl \& Wissing 1987, Ahlgren 1990b), and its nutritional contribution is uncertain. The fact that detritus does not produce positive growth in omnivorous fishes has often been interpreted to mean that detritus provides little nutritive value (Ahlgren 1990b). This view assumes that all foods are qualitatively similar. An alternate interpretation would be that detritus is lacking in some essential compounds needed for growth. Some of these nutritional deficiencies could be counteracted if an individual consumed additional food such as invertebrates. Detritus is low in amino acids that are generally important for growth (Bowen 1987, Ahlgren 1990b).

The mixed diet of limited Artemia and unlimited marine snow was designed to reflect natural conditions, but fish failed to exhibit positive growth on this diet (Table 2). If natural conditions were reproduced, one would expect to see growth rates similar to those of mullet in the wild, about $2 \% \mathrm{~d}^{-1}$ (calculated from Thomson 1963). There are several possible explanations for this discrepancy. First, Artemia may not be nutritionally similar to copepods, the most common invertebrate food for juvenile mullet (Pisarevskaya \& Aksenova 1991). A second possible explanation is that the experimental situation was not representative of the natural environment. Artemia concentrations were set to the average concentrations of copepods in coastal waters (Fulton 1984). These figures assume that copepods are uniformly distributed throughout coastal waters. Zooplankton populations are often patchily distributed (Wiebe 1970, Levin \& Segel 1976, Riley 1976), and this patchiness may affect feeding success of fish populations (Govoni et al. 1985). Because marine snow is ubiquitous in coastal regions (Alldredge \& Silver 1988), juvenile mullet might use marine snow to slow weight loss when they are between patches of zooplankton.

A third possible explanation for the poor growth of mullet feeding on marine snow of the mixed diet is that the unlimited marine snow may not have been unlim- ited in the true sense of the word. There was an average of 292 aggregates per tank. If a fish consumed a mean of 10 aggregates $\mathrm{h}^{-1}$ and they consumed at the same rate (even though it is unlikely) throughout a $24 \mathrm{~h}$ period in the growth experiment, it would consume nearly all the aggregates in a tank. If the food quality of marine snow varies from aggregate to aggregate, and mullet can sense these differences, then the marine snow left at the end of a $24 \mathrm{~h}$ feeding period may be unpalatable to the mullet. Detritus can contain high quantities of phenolic acids that increase in concentration with age of detritus and may reduce its palatability (Valiela \& Reitsma 1984). Ahlgren (1990b) found that white suckers are capable of evaluating the quality of detritus and selecting the higher quality particles for consumption. Mullet possess taste buds on the pharyngeal filtering apparatus (Hossler \& Merchant 1983), which might be used to select higher quality detritus for consumption. If the quality of marine snow does vary from aggregate to aggregate, and mullet are capable of detecting these differences, then they would presumably stop eating after all palatable aggregates had been consumed and, hence, they may not have been consuming marine snow to satiation.

The poor growth of the mullet fed marine snow in the growth experiments may have been due to stress. There was high mortality of white mullet in feeding trials (Table 2). The experimental conditions of being sealed in a $3 \mathrm{l}$ Plexiglas tank for $24 \mathrm{~h}$ at a time may have increased stress to a level that did not allow some of the fish to survive the $14 \mathrm{~d}$ experiment. While there was not a noticeable oxygen depletion in the tanks over a $24 \mathrm{~h}$ period, other stressors such as an increase in dissolved nitrogen concentrations were not monitored. Ahlgren (pers. comm.) found white suckers to be stressed after $21 \mathrm{~d}$ of growth experiments; however, the suckers were not sealed in the experimental tanks. It is reasonable to assume then that white mullet would be stressed after $14 \mathrm{~d}$ of being completely sealed in the experimental tank for $24 \mathrm{~h}$ at a time.

The tanks used in this study were 31 in size. The small size of the experimental containers could have served to decrease feeding. While the mullet appeared to be feeding at a reasonable level, they might not have fed as much as they would have in the wild. If this were the case, then this would result in lower SGR. Blaxter (1980) suggested that growth of fish in the laboratory depends on available space. Fish in smaller tanks may grow more slowly and be less healthy (Theilacker 1980). Laboratory rearing has been shown to produce slower growth rates than those reported for wild counterparts (Bailey \& Stehr 1986). These effects may also be an important explanation for the poor growth rates of mullet in this study. 
Mullet might not be as efficient as other omnivores at digesting amino acids derived from detritus. The assimilation efficiency of $49.2 \%$ for organic matter of marine snow is within the range of $\% \mathrm{AE}$ estimates ( 20 to $75 \%$ ) for fish feeding on detritus in their natural habitats (Ahlgren 1989). The assimilation of amino acids in marine snow by mullet ( $55.7 \%$ ), was lower than estimates for Tilapia sp. (72\%) and for white sucker (68.9\%) feeding on detritus (Ahlgren 1989). White suckers (Ahlgren $1990 \mathrm{~b})$ also exhibited better growth on detritus $\left(-0.66 \% \mathrm{~d}^{-1}\right)$ than juvenile striped mullet did on marine snow $\left(-1.34 \% \mathrm{~d}^{-1}\right)$, which may indicate that mullet process amino acids in detritus less efficiently than do suckers. Juvenile striped mullet also processed organic matter $(10 \%)$ less efficiently than juvenile white suckers, but amino acids are more important for growth than is total organic matter (Bowen 1987).

Herbivorous animals are able to make changes in their ability to assimilate different materials to compensate for changes in the diet (Prosser \& DeVillez 1991). The fish in this study were maintained in holding tanks for 3 to $14 \mathrm{~d}$ prior to the experiments. Because they were maintained on a diet of ground herbivore fish food, they might have been exposed to higher levels of amino acids than encountered in the wild. The mullet may have experienced changes in digestive physiology during the period they were held in the laboratory prior to the beginning of the experiments, which could have resulted in decreased assimilation efficiency and decreased growth on a diet of marine snow.

The stomach contents of juvenile striped mullet collected in the Charleston Harbor estuary looked nearly identical to the stomach contents of mullet fed marine snow in the laboratory. This suggests that the striped mullet from the Charleston harbor were feeding on marine snow. Detrital material from the stomach of juvenile striped mullet collected of fshore looked similar to material from stomachs of fish fed marine snow in the laboratory and, hence, may have been feeding on marine snow as well. Invertebrates found in the guts of these mullet (harpacticoid copepods, larval polychaetes, and nematodes) are concentrated on marine snow (Shanks \& Edmondson 1990). Because such a large percentage of the nematodes in the water column are in marine snow, it is unlikely that a fish could ingest a nematode without actively ingesting marine snow (Shanks \& Edmondson 1990). Shanks \& Edmondson (1990) observed that for an estuarine environment $80 \%$ of all nematodes and competent polychaete larvae in the water column were on marine snow. Because the volume of detritus and zooplankton were nearly equal in the stomachs of field-collected juvenile striped mullet, it appears as though they may have been consuming marine snow and invertebrates at similar rates.
This study has demonstrated that juvenile mullet actively ingested marine snow in the laboratory. No previous study has documented the consumption of marine snow by fishes. Gut-content analyses of fieldcaught juvenile mullet suggest that these laboratory experiments have relevance to the natural environment. Consumption of marine snow may prevent weight loss in juvenile mullet, especially when complemented with zooplankton. The assimilation efficiencies of nutrients from marine snow consumed by juvenile mullet were comparable to those found for other fishes feeding on detritus.

Acknowledgements. We thank K. del Carmen, G. Riekerk, and $M$. Reeder for their assistance in the field and laboratory and E. Wenner for statistical assistance. We gratefully acknowledge P. Bass for providing striped mullet. M. Ahlgren provided helpful comments on this manuscript. This study was supported by grants from the Lerner-Gray Fund for Marine Research, Sigma Xi, and the Slocum-Lunz Foundation to ETL, and by Grant No. OCE-9017807 from the National Science Foundation to ALS. This is contribution No. 125 from the Grice Marine Biological Laboratory, University of Charleston, South Carolina.

\section{LITERATURE CITED}

Ahlgren MO (1989) Diet selection and the nutritional significance of facultative detritivory by the juvenile white sucker, Catostomus commersoni. PhD dissertation, Michigan Technological University

Ahlgren MO (1990a) Diet selection and the contribution of detritus to the diet of the juvenile white sucker (Catostomus commersoni). Can J Fish Aquat Sci 47:41-48

Ahlgren MO (1990b) Nutritional significance of facultative detritivory to the juvenile white sucker (Catostomus commersoni). Can J Fish Aquat Sci 47:49-54

Alldredge AL (1976) Discarded appendicularian houses as sources of food, surface habitats, and particulate organic matter in planktonic environments. Limnol Oceanogr 21: $14-23$

Alldredge AL, Silver MW (1988) Characteristics, dynamics, and significance of marine snow. Prog Oceanogr 20:41-82

Allen G (1981) Methods for the detection of peptides. In: Work TS, Burdon RH (eds) Laboratory techniques in biochemistry and molecular biology, Vol 9. Sequencing of proteins and peptides. North-Holland Publishing, New York, p 135-160

Bailey KM, Stehr CL (1986) Laboratory studies on the early life history of the walleye pollock. Theragra chalcogramma (Pallas). J exp mar Biol Ecol 99:233-246

Banse K (1990) New view on the degradation and deposition of organic particles as collected by sediment traps in the open sea. Deep Sea Res 37:1177-1195

Blaxter JHS (1976) Reared and wild fish - how do they compare? In: Persoone G, Jaspers E (eds) Proc 10th Eur mar Biol Symp, Vol 1. Universa Press, Wetteren, p 11-26

Bochdansky AB, Herndl GJ (1992) Ecology of amorphous aggregations (marine snow) in the Northern Adriatic Sea. 3. Zooplankton interactions with marine snow. Mar Ecol Prog Ser 87:135-146

Bowen SH (1987) Composition and nutritional value of detritus. In: Moriarity DJW, Pullin RSV (eds) Detritus and microbial ecology in aquaculture. ICLARM, Manila, $p$ $192-216$ 
Buddington RK (1980) Hydrolysis resistant organic matter as a reference for measurement of fish digestive efficiency. Trans Am Fish Soc 109:653-656

Carr WES (1976) Chemoreception and feeding behavior in the pigfish, Orthopristis chrysopterus: characterization and isolation of stimulatory substances extracted from shrimp. Comp Biochem Physiol 55A:153-157

Ching CV (1977) Studies on the small grey mullet Liza malinoptera (Valenciennes). J Fish Biol 11:293-308

Conover RJ (1966) Assimilation of organic matter by zooplankton. Limnol Oceanogr 11:338-345

De Silva SS, Wijeyarante MJS (1977) Studies on the biology of young grey mullet Mugil cephalus L. II. Food and feeding. Aquaculture 12:157-167

Ehlinger TJ (1989) Foraging mode switches in the golden shiner (Notemigonus crysoleucas). Can J Fish Aquat Sci 46:1250-1254

Eisma D (1986) Flocculation and de-flocculation of suspended matter in estuaries. Neth J Sea Res 20:183-199

Friedland KD, Haas LW, Merriner JV (1984) Filtering rates of the juvenile Atlantic menhaden Brevoortia tyrannus (Pisces: Clupeidae), with consideration of the effects of detritus and swimming speed. Mar Biol 84:109-11.7

Fulton RS III. (1984) Distribution and community structure of estuarine copepods. Estuaries 7:38-50

Gerber RP, Marshall N (1974) Ingestion of detritus by the lagoon pelagic community at Eniwetok Atoll. Limnol Oceanogr 19:815-824

Goh Y, Tamura T (1980) Effect of amino acids on the feeding behavior in red sea bream. Comp Biochem Physiol 66C: $225-229$

Govoni JJ,Chester AJ, Hoss DE, Ortner PB (1985) An observation of episodic feeding and growth of larval Leiostomous xanthurus in the northern Gulf of Mexico. J Plankton Res 7:137-146

Hossler FE, Merchant LH (1983) Morphology of taste buds on the gill arches of the mullet Mugil cephalus, and the killifish Fundulus heteroclitus. Am J Anat 166:299-312

Johnson PC, Vinyard GL (1987) Filter-feeding behavior and particle retention efficiency of Sacramento blackfish Trans Am Fish Soc 116:634-640

Lasiak T, McLachlan A (1987) Opportunistic utilization of mysid shoals by surf zone teleosts. Mar Ecol Prog Ser 37:1-7

Leong RJH, O'Connell CP (1969) A laboratory study of particulate and filter feeding of the northern anchovy (Engraulis mordax). J Fish Res Bd Can 26:557-582

Levin SA, Segel LA (1976) Hypothesis for origin of planktonic patchiness. Nature 259:659

Lewis VP, Peters DS (1984) Menhaden - a single step from vascular plant to fishery harvest. J exp mar Biol Ecol 84:95-100

Lowe-McConnell RH (1964) The fishes of the Rapununi savanna district of British Guiana, South America. I. Ecological groupings of fish species and effects of seasonal cycle on the fish. J Linn Soc (Zool) 45:103-145

Marais JFK (1980) Aspects of food intake, food selection, and alimentary canal morphology of Mugil cephalus (Linnaeus, 1858), Liza tricuspidens (Smith, 1935), L. richardsoni (Smith, 1846), and L. dumerili (Steindachner, 1869). J exp mar Biol Ecol 44:193-209

McIntyre SC Jr (1983) Flocculated algae, a potentially important food source for filter feeding fish. J Freshwat Ecol 2: 193-196

Moriarity DJW (1976) Quantitative studies on bacteria and algae in the food of the mullet Mugil cephalus L. and the prawn Metapenaeus bennetae (Recek \& Dall). J exp mar Biol Ecol 22:131-143
Mundahl ND, Wissing TE (1987) Nutritional importance of detritivory in the growth and condition of gizzard shad in an Ohio resivoir. Environ Biol Fish 20:129-142

Odum WE (1968a) The ecological significance of fine particle selection by the striped mullet Mugil cephalus. Limnol Oceanogr 13:92-98

Odum WE (1968b) Mullet grazing on a dinoflagellate bloom Chesapeake Sci 9:202-204

Pisarevskaya II, Aksenova EO (1991) Feeding of Black Sea mullets during early ontogeny. J Ichthyol 31:22-30

Prejs A, Prejs K (1987) Feeding of tropical freshwater fishes: seasonality in resource availablity and resource use. Oecologia 71:397-404

Prinslow TE, Valiela I, Teal JM (1974) The effect of detritus and rationsize on the growth of Fundulus heterocitus (L.) $\mathrm{J}$ exp mar Biol Ecol 16:1-10

Prosser CL, DeVillez EJ (1991) Feeding and digestion. In: Prosser CL (ed) Environmental and metabolic animal physiology. John Wiley \& Sons, Inc, New York, p 205-229

Ricker WE (1979) Growth rates and models. In: Hoar WS, Randall DJ, Brett JR (eds) Fish physiology, Vol 8. Academic Press. New York, p 677-743

Riley GA (1976) A model of plankton patchiness. Limnol Oceanogr 21:873-880

Romer GS, McLachlan A (1986) Mullet grazing on surf diatom accumulation. J Fish Biol 28:93-104

Shanks AL, Edmondson EW (1989) Laboratory-made artificial marine snow: a biological model of the real thing. Mar Biol $101: 463-470$

Shanks AL, Edmondson EW (1990) The vertical flux of metazoans (holoplankton, meiofauna, and larval invertebrates) due to their association with marine snow. Limnol Oceanogr 35:455-463

Silver MW, Shanks AL, Trent JD (1978) Marine snow: microplankton habitat and source of small-scale patchiness in pelagic populations. Science 201:371-373

Suh HL, Todâ T, Terazaki M (1991) Diet of calyptopes of the euphausid Euphausia pacifica in the Yellow Sea. Mar Biol 111:45-48

Theilacker GH (1980) Rearing container size affects morphology and nutritional condition of larval jack mackerel, Trachurus symmetricus. Fish Bull US 78:789-791

Thomson JM (1954) The organs of feeding and the food of some Australian mullet. Aust J mar Freshwat Res 5:469-485

Thomson JM (1963) Synopsis of biological data on the grey mullet, Mugil cephalus Linnaeus 1758. Circ Div Fish Oceanogr CSIRO, Synopsis No 1

Trent JD, Shanks AL, Silver MW (1978) In situ and laboratory measurements on macroscopic aggregates in Monterey Bay, Calıfornia. Limnol Oceanogr 23:626-635

Valiela I, Reitsma CS (1984) Nitrogen, phenolic acids, and other feeding cues for salt marsh detritovores. Oecologia 63:350-356

Wenner CA, Barans CA, Stender BW, Berry FW (1.979) Results of MARMAP otter trawl investigations in the South Atlantic Bight. IV Spring, 1975. S C mar Res Cent Tech Rep 44:1-59

Wenner EL, Shealy MH Jr, Sandifer PA (1982) A profile of the fish and decapod crustacean community in a South Carolina estuarıne system prior to flow alteration. NOAA Tech Rep NMFS SSRF 757

Wiebe PH (1970) Small-scale spatial distribution in oceanic zooplankton. Limnol Oceanogr 15:205-217

Wright DJ, O'Brien WJ, Lueke C (1983) A new estimate of zooplankton retention by gill rakers and its ecological significance. Trans Am Fish Soc 112:638-646 